Dicle Tip Dergisi / Dicle Med J (2018) 45 (3) : 357-360

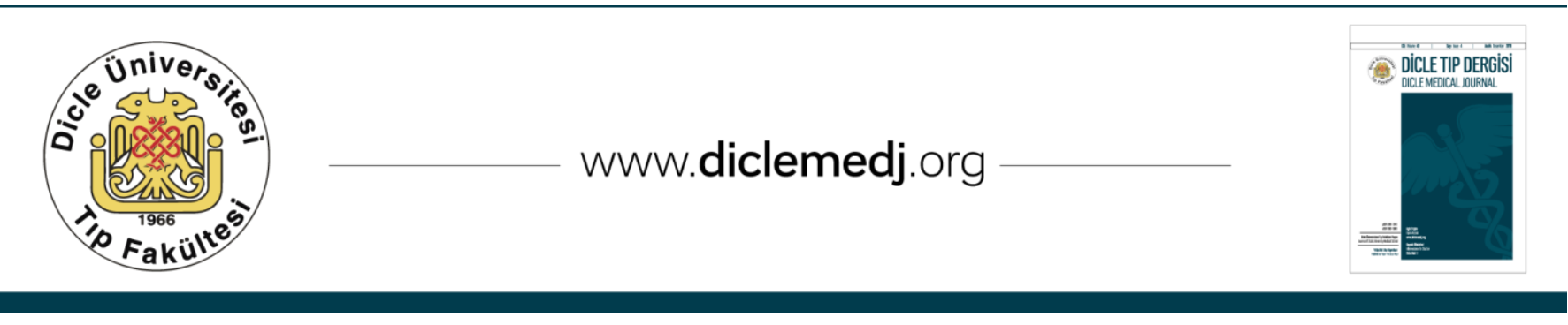

Olgu Sunumu / Case Report

\title{
Fenilketonürili Hastada Anestezi Yönetimi
}

\author{
Enes Çelik ${ }^{1}$, Zeynep Baysal Yıldırım² ${ }^{2}$ Feyzi Çelik ${ }^{3}$, Abdulmenap Güzel ${ }^{4}$, Yusuf İpek ${ }^{5}$
}

1 Dicle Üniversitesi Tıp Fakültesi Anesteziyoloji ve Reanimasyon AD Diyarbakır, Türkiye ORCID: 0000-0002-5546-4924

2 Dicle Üniversitesi Tip Fakültesi Anesteziyoloji ve Reanimasyon AD Diyarbakır, Türkiye ORCID: 0000-0002-5264-1972

3 Dicle Üniversitesi Tıp Fakültesi Anesteziyoloji ve Reanimasyon AD Diyarbakır, Türkiye ORCID: 0000-0001-5986-8785

4 Dicle Üniversitesi Tıp Fakültesi Anesteziyoloji ve Reanimasyon AD Diyarbakır, Türkiye ORCID: 0000-0003-2261-0072

5 Şanlıurfa Balıklıgöl Devlet Hastanesi, Şanlıurfa, Türkiye ORCID: 0000-0002-2302-9434

Öz

Bu olgu sunumunda 12 yaşında , Fenilketonüri (FKÜ) tanısı almış hastanın vitreo-retinal cerrahi sırasındaki anestezi yönetimini paylaşmak istedik. Ülkemizde akraba evliliğinin yüksek oranda olması nedeniyle FKÜ gibi otozomal resesif kalıtılan hastalıklar daha sık görülmektedir. Klasik FKÜ görülme sıklığı dünyada 1:10000 iken bu oran ülkemizde 1:6094'dir. Her yıl ülkemizde 250-300 çocuk bu hastalıkla doğmakta ve her 20-25 kişiden biri bu hastalı̆̆ taşımaktadır. Bölgemizde akraba evliliğinin yüksek sıklıkta olması ve FKÜ hastalarında maksilla hipoplazisi,mental retardasyon,mikrosefali ve B12 vitamin metabolizması bozukluğu gibi geniş perspektifte klinik özelliklerin olması nedeniyle genel anestezi tecrübemiz paylaşlmıştır.

Anahtar Kelimeler: Fenilketonüri, genel anestezi, maksilla hipoplazisi, mikrosefali.

DOI: $10.5798 /$ dicletip. 457277

Yazışma Adresi / Correspondence: Enes Çelik, Dicle Üniv. Tıp Fakültesi Hast., Anesteziyoloji ve Reanimasyon AD.e-mail: ec_1907@hotmail.com.tr 


\title{
Anesthesia Management in Phenylketonuria Patient
}

\begin{abstract}
In this case report, we wanted to share the anesthesia management for vitreo-retinal surgery of a 12 year-old patient with Phenylketonuria (FKU).Autosomal recessive diseases like FKU are more common because of the high proportion of consanguineous marriages in our country. The incidence of classical FKU is 1: 10000 in the world while it is 1 : 6094 in our country. Every year 250-300 children in our country are born with this disease and every 20-25 people carry this disease. Our general anesthesia experience has been shared because of the high frequency of consanguineous marriages in our region and the clinical features in a wide perspective such as maxillary hypoplasia, mental retardation, microcephaly and vitamin B12 metabolism disorder in FKU patients.
\end{abstract}

Keywords: Phenylketonuria, general anesthesia, maxillary hypoplasia, microcephaly.

\section{GíRIS}

Fenilketonüri (FKÜ) konjenital bir protein metabolizma bozukluğudur. Karaciğerden salgilanan fenilalanin hidroksilaz (FAH) enziminin yokluğu veya yetersizliği nedeni ile fenilalanin (FA) metabolize edilememektedir. Sonuç olarak plazma FA düzeyi normalin 20-30 katı kadar artmakta, protein sentezi baskılanmakta, serotonin, dopamin ve norepinefrin nörotransmitterlerinde belirgin düşüşler izlenmekte ve miyelin sentezi azalmaktadır ${ }^{1}$ Klinik bulguları, ciddi entelektüel gerilik, nöbetler, otizm benzeri davranış paterni, mikrosefali, raş, biriken fenilasetik asite bağlı koku ve hipopigmentasyondur².

Ülkemizde akraba evliliğinin \%29 gibi yüksek oranda olması nedeniyle FKÜ gibi otozomal resesif olan hastalıklar daha sık görülmektedir. Klasik FKÜ görülme sıklı̆̆ dünyada 1:10000 iken bu oran ülkemizde 1:6094'dir. Her yll ülkemizde 250-300 çocuk bu hastalıkla doğmakta ve her 20-25 kişiden biri bu hastalığ taşımaktadır ${ }^{3}$.

Olgu sunumunda FKÜ tanısı almış retina dekolmanı nedeniyle vitreo-retina cerrahisi geçirecek hastanın, anestezi yönetimi literatür eşliğinde paylaşılmıştır.

\section{OLGU}

On iki yaşında kız retina dekolmanı nedeniyle vitreo-retina cerrahisi planlanan hastanın preoperatif muayenesinde FKÜ hastası olduğu öğrenildi. Hastanın ebeveynleri akraba idi. Tanısı 3 yaşında konulmuş olan hastada mental gerilik mevcuttu. Maksilla hipoplazisi mevcuttu. Hastanın karaciğer ve böbrek fonksiyon testleri normal olup hastanın diğer laboratuar tetkiklerinde patoloji yoktu.

Operasyon öncesi hastada maksilla hipoplazisi mevcut olması nedeniyle zor ventilasyon ve zor entübasyon olabileceği göz önüne alınarak farlı boyutta Endotrakeal tüp, I-gel, Mac coy zor entübasyon bleydi ve video-laringoskop hazırlandı. Anestezi indüksiyonunda $1 \mathrm{mg} / \mathrm{kg}$ lidokain, $1,5 \mathrm{mg} / \mathrm{kg}$ propofol, $1 \mathrm{mcg} / \mathrm{kg}$ fentanil intravenöz yolla uygulandı. Ventilasyonunda sıkıntı görülmeyen hasta $0,6 \mathrm{mg} / \mathrm{kg}$ rocuronyum verildikten yaklaşı $2 \mathrm{dk}$ sonra entübe edildi. Anestezi idamesinde \%1,5-2 sevofluran ve $\% 50$ hava/oksijen kullanıldı. İntraoperatif arterial kan gazı analizi yapıldı. Kan basıncl, kalp atım sayısı, end-tidal karbondioksit, Sp02, vücut sicaklı̆̆ mönitörizasyonu ile takip edildi. Nitröz oksit kullanılmayan anestezi idamesinde anestezik komplikasyon yaşanmadı. 


\section{TARTIŞMA}

Genetik bozuklukları olan çocuklar iskelet deformitelerinden çeşitli organ anomalilerine, mental geriliklere, metabolik hastalıklara sahip olduklarından, cerrahi bir işlem gerektiğinde anestezileri özel bir önem arz etmektedir. $\mathrm{Bu}$ hastalara yaklaşımda ortaya çıkabilecek komplikasyonlar ve anestezik maddelerle etkileşim hakkında bilgi sahibi olmak gerekmektedir.

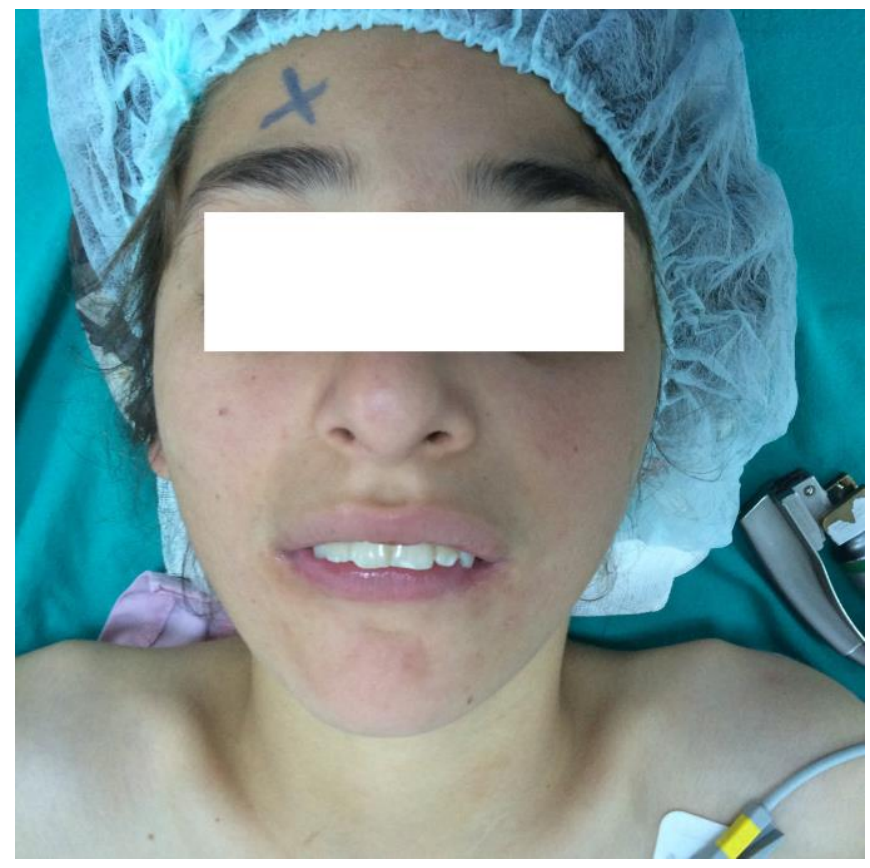

Resim 1. Entübasyondan önce hastanın görünümü

Doğumda fenilketonürili bebekler normaldirler. Bazı vakalarda pilor stenozu ile karıșılabilen inatçı kusmalar tanımlanmıştır. Zaman içinde nörolojik bulgular görülmeye başlanır. Yavaş gelişen mental retardasyon çevreye ilgisizlik, hiperaktif derin tendon refleksleri ile beraber hipertonisite, atetoz, nöbet, EEG anomallikleri ve mikrosefali önemli bulgulardır ${ }^{4}$. Seboraik ve egzamatik cilt lezyonları olabilmektedir. Geniş aralıklı dișlerle birlikte mine hipoplazisi ve büyüme geriliği görülebilir. Hastamızın maksilla hipoplazisi, retina dekolmanı
Bu hastaların preoperatif hazırlığında karaciğer fonksiyon testleri, böbrek fonksiyon testleri, açlık kan șekeri, Vitamin B12 düzeyi, tam kan sayımı, fenilalanin düzeyi çalışılmalıdır.

Fenilketonürili hastaları preoperatif değerlendirmelerinde amino asit metabolizmasına katılan enzimlerin artmış aktivitesini ve glikoliz veya protein katabolizmasında aşırı artışı önlemek önemlidir. Preoperatif açlık ve cerrahi stresin katabolizmaya neden olabileceği göz önünde bulundurulmalıdır5. Önerilen Fenilketonürili hastaların bekletilmeden ilk vaka olarak ameliyata alınmalarıdır. Hastamız cerrahi bölümle konuşularak ilk vaka olarak cerrahiye alındı.

Anestezi sirasinda bu hastalarda monitörizasyon ayrı bir önem taşımaktadır. Özellikle vücut sıcaklığı, kapnografi, kan şekeri ve arteryel kan gazı analizinin sürekli ölçümü istenmektedir 6 Hastamız cerrahi süresince normotermik, normoglisemik ve normokarbik olarak izlendi. Operasyon süresince aralıklı kan şekeri ölçümleri, end-tidal karbodioksit 28-32 mmHg olacak şekilde mekanik ventilatör ayarları yapıldı.

Fenilketonürili hastalarda prokonvülzan anestezik ilaçların kullanımında dikkatli olunmalıdır. Anestezide kullanılan inhalasyon ve intravenöz anestezik ajanların anormal EEG ve nöbet benzeri motor aktiviteye neden olduğu gösterilmiştir. İnhalasyon anesteziklerinden enfluran sevofluran, intravenöz kullanılanlardan ketamin, etomidat ve propofolün prokonvülzan oldukları unutulmamalıdır?

Perioperatif dönemde olası nöbet gelişimi ihtimaline karşı ilaç olarak midazolam hazırda bulunduruldu. Benzer çalıșmalarda da midazolamın kısa etkili antikonvülzan ve sedatif ajan olması ve çeșitli yollardan (im, iv, oral) uygulanabilmesi nedeniyle tercih edildiğini görüldü ${ }^{5}$. 
Zor veya başarısız ventilasyon ve endotrakeal entübasyon anestezistlerinen en çok çekindikleri durumlardandır. Zor entübasyon birden fazla girişim ve yardımcı aletlerin kullanılması olarak tanımlanmaktadır. Pediatrik hasta grubunda kullanılan test ve yöntemler sınırlı olmaktadır. Hastalarda mevcut olan anomaliler entübasyon zorluğu için kuvvetli bir ipucudur. Hastamızda mevcut olan maksilla hipoplazisi nedeniyle anestezinde zor ventilasyon ve entübasyon hazırlığı yapıldı. Zor hava yolu olacağı düşünülen hastalarda ön hazırlık yapılması, hem entübasyon işlemini kolaylaştırır hem de olası komplikasyonları azaltır. Anestezi hazırlığında; her tip ve çapta tüp, laringoskop ve değişik bleytler, magill pensi, I-gel, video-laringoskop hazırlandl. Hastamızın entübasyonu C MAC videolaringoskop ile gerçekleştirildi.

Bilindiği gibi videolaringoskoplar zor entübasyon beklenen hastaların entübasyonu için tasarlanmış olup, blade'inin uç kısmına yerleştirilmiş bir optik sistem aracilığıyla indirekt bir görüşe izin vermektedir. Bu sayede entübasyon ve laringoskopide farklı bir yaklaşım olarak kabul edilmektedir. Yapılan çalışmalar bu cihazların laringoskopik görünümü iyileştirdiği, endotrakeal entübasyon için kurtarıcı araç olarak kullanılabilineceği gösterilmektedir ${ }^{8,9}$.

Fenilketonüri olgularının anestezi yönetimi özellik arz eder. Bu hastalardaki ek anomaliler ve bunların riskleri düşünülerek anestezi indüksiyon ve entübasyonunda yaşanabilecek problemlerin olabileceği unutulmamalıdır. Zor entübasyon olasılığına karşı videolaringoskopi dahil olmak üzere tüm hazırlıklar tamamlanmalıdır.
Çıkar Çatışması Beyanı: Yazarlar çıkar çatışması olmadığını bildirmişlerdir.

Finansal Destek: Bu çalıșma her hangi bir fon tarafından desteklenmemiştir.

Declaration of Conflicting Interests: The authors declare that they have no conflict of interest.

Financial Disclosure: No financial support was received.

\section{KAYNAKLAR}

1. Prasad C, Dalton L, CDE R, Levy H. Role of diet therapy in management of hereditary metabolic diseases. Nutr Research 18,1998; 2: 391-402.

2. Kayaalp E, Treacy E, Waters PJ, Byck S, Nowacki P, Scriver CR. Human phenylalanine hydroxylase mutations and hyperphenylalaninemia phenotypes: A metanalysis of genotypephenotype correlations. Am J Hum Genet 1997; 61: 1309-17.

3. Kızılelma A, Şirin H, Acıcan D, et al. Türkiyede ulusal yenidoğan fenilketonüri taraması sonuçları. 19. Ulusal Neonatoloji Kongresi Kitabı 2011: 27.

4. Blau N, Spronsen, FJ, Levy HL. Phenylketonuria The Lancet 2010; 376: 1417-27.

5. Dal D, Celiker V. Anaesthetic management of a strabismus patient with phenylketonuria. Paediatr Anaesth. 2003 Oct; 13: 740-1.

6. Jackson SH. Genetic and metabolic diseases. In: Katz J, Benumof JL, Kadis LB, eds. Inborn Errors of Metabolism. Anaesthesia and Uncommon Diseases, 3rd edn. Philadelphia: W.B. Saunders Co., 1990: 43-55.

7. Coleman, Jamie J. Adverse Drug Reactions. Clinical Medicine. 2016; 16: 481-5.

8. Cavus E, Callies A, Doerges V, Heller G, Merz S, Rosch P, et al. The C-MAC videolaryngoscope for prehospital emergency intubation: a prospective, multicentre, observational study. Emerg Med J 2011; 28: 650-3.

9. Hackell, R., Held, L., Stricker, P., Fladjoe, J.E.,. Management of the difficult infant airway with the Storz Video Laryngoscope: a case series. Anesth. Analg. 2009; 109: 763-66. 